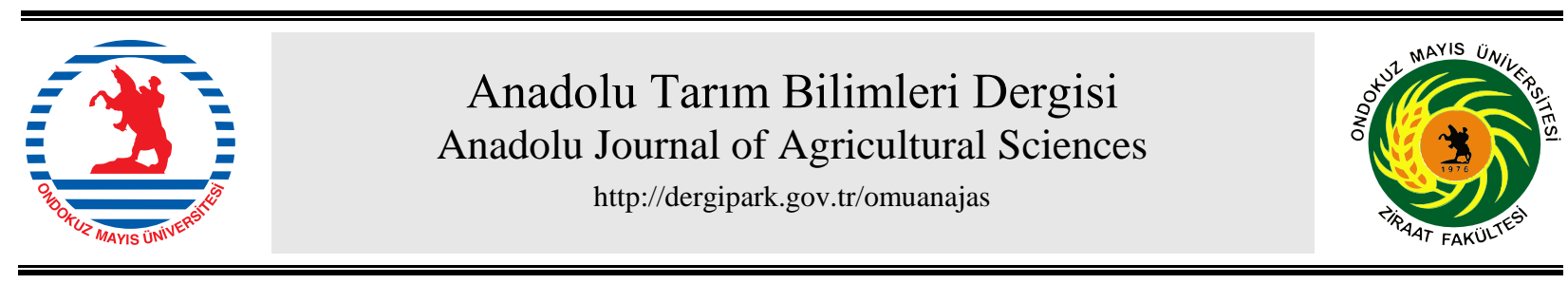

Araştırma/Research

Anadolu Tarım Bilim. Derg./Anadolu J Agr Sci, 34 (2019)

ISSN: 1308-8750 (Print) 1308-8769 (Online)

doi: 10.7161/omuanajas.529247

\title{
Bazı siklamen türlerinde farklı doku kültürü ortamlarının gynogenesis üzerine etkileri
}

\author{
Mehmet Tütüncü ${ }^{a *}$, Muharrem Özcan $^{\mathrm{a}}$, Yeşim Yalçın Mendi ${ }^{\mathrm{b}}$ \\ ${ }^{a}$ Ondokuz Mayls Üniversitesi Ziraat Fakültesi Bahçe Bitkileri Bölümü, Samsun \\ ${ }^{b}$ Çukurova Üniversitesi Ziraat Fakültesi Bahçe Bitkileri Bölümü, Adana \\ "Sorumlu yazar/corresponding author: mehmet.tutuncu@omu.edu.tr
}

Geliş/Received 19.02.2019 Kabul/Accepted 29/07/2019

\begin{abstract}
ÖZET
Siklamende görülen kendileme depresyonu, farklı ploidi seviyeleri, kendine uyuşmazlık ve abortif embriyo oluşumu nedeniyle klasik yöntemlerle siklamen 1slahı oldukça zordur. Bu nedenle in vitro haploidizasyon, siklamen ıslahında yaygın olarak kullanılmaktadır. $\mathrm{Bu}$ çalışmada in vitro haploidizasyon ve in vitro çoğaltımın ilk aşaması olarak bitki doku kültürü ortamlarının ve hormonların etkisi araştırılmıştır. Çalışmada bitkisel materyal olarak, Cyclamen persicum ve Cyclamen pseudibericum'un ovül eksplantları, ortam olarak ise 2,4-dichlorophenoxyaceticacid (2,4-D) ve 6- $(\gamma, \gamma-$ dimethylallylamino) purine' (2iP)'in farklı konsantrasyonlarını içeren $1 / 2 \mathrm{MS}$ ve B5 ortamları kullanılmıştır. Çalışma sonucunda, Cyclamen persicum türünde en iyi kallus oluşum oranı; $1.5 \mathrm{mg} \mathrm{L}^{-1}$ (2,4-D ve $0.5 \mathrm{mg} \mathrm{L}^{-1}$ 2iP içeren B5 ortamından (\%70 oranında) elde edilmiştir. Cyclamen pseudibericum türü için ise kallus oluşum oranı $\% 48$ olmuş ve $1 \mathrm{mg} \mathrm{L}^{-1} 2,4-\mathrm{D}$ ve $0.3 \mathrm{mg} \mathrm{L}^{-1} 2 \mathrm{iP}$ içeren B5 ortamından elde edilmiştir. Cyclamen persicum türünde en yüksek embriyo uyartımı $1.5 \mathrm{mg} \mathrm{L}^{-1} 2,4-$ $\mathrm{D}$ ve $0.8 \mathrm{mg} \mathrm{L}^{-1} 2 \mathrm{iP}$ içeren $1 / 2 \mathrm{MS}$ ortamında gelişen kalluslardan elde edilmiştir (\%55). Ancak Cyclamen pseudibericum türünde besi ortamlarının hiç birinden embriyo uyartımı sağlanamamıştır. Sonuç olarak, kallus uyartımında B5 ortamı, 1/2MS ortamından daha iyi sonuç vermesine rağmen embriyo uyartımı için yüksek oksin ve düşük sitokinin konsatrasyonuna sahip $1 / 2 \mathrm{MS}$ ortamı daha iyi bulunmuş ve $2.0 \mathrm{mg}$ $\mathrm{L}^{-1} 2,4-\mathrm{D}$ ve $0.5 \mathrm{mg} \mathrm{L}^{-1} 2 \mathrm{iP}$ içeren $1 / 2 \mathrm{MS}$ ortamından 42 adet bitkicik elde edilmiştir.
\end{abstract}

\section{Effects of different tissue culture media on gynogenesis in some cyclamen species}

\section{ABSTRACT}

Cyclamen breeding is difficult due to selfing depression different ploidy levels, self-incompatibility and abortive embryo formation. Therefore, in vitro haploidisation is commonly used in cyclamen breeding. In this study, we investigated effects of different tissue culture media and plant hormones as a first of in vitro haploidisation and propagation. We used ovule explants from Cyclamen persicum and Cyclamen pseudibericum on $1 / 2 \mathrm{MS}$ and B5 culture mediums supplemented with different concentration of 2,4dichlorophenoxyaceticacid (2,4-D) and 6- $(\gamma, \gamma-$ dimethylallylamino) purine (2iP). According to results best callus formation rate was $70 \%$ obtained from B5 medium supplemented with $1.5 \mathrm{mg} \mathrm{L}^{-1} 2,4-\mathrm{D}$ and $0.5 \mathrm{mg} \mathrm{L}-12 \mathrm{iP}$ in Cyclamen persicum. It was $48 \%$ on B5 medium supplemented with $1 \mathrm{mg} \mathrm{L}^{-1} 2,4-\mathrm{D}$ and $0.3 \mathrm{mg} \mathrm{L}^{-1} 2 \mathrm{iP}$ in Cyclamen pseudibericum. In Cyclamen persicum, highest embryo induction rate was $55 \%$ obtained from callus regenerated on $1 / 2 \mathrm{MS}$ medium supplemented with $1.5 \mathrm{mg} \mathrm{L}^{-1} 2,4-\mathrm{D}$ and $0.8 \mathrm{mg} \mathrm{L} \mathrm{L}^{-1}$ 2iP. However, embryo induction was not obtained on any medium for Cyclamen pseudibericum. Overall, $1 / 2 \mathrm{MS}$ culture medium supplemented with high auxin and low cytokinin concentration is better for embryo induction although B5 medium was better than $1 / 2 \mathrm{MS}$ medium for callus formation and 42 plantlets obtained only from callus regenerated on $1 / 2 \mathrm{MS}$ medium supplemented with $2.0 \mathrm{mg} \mathrm{L}^{-1} 2,4-\mathrm{D}$ and $0.5 \mathrm{mg} \mathrm{L}^{-1} 2 \mathrm{iP}$.
Anahtar Sözcükler:

Süs bitkisi

Doku kültürü

Kallus

Rejenerasyon

Oksin

Sitokinin

Keywords:

Ornamental plant

Tissue culture

Callus

Regeneration

Auxin

Cytokinine lisans tezinden üretilmiştir. 


\section{Giriş}

Çiçek soğanları, 800'den fazla botanik cinsi barındıran, değişen çevresel faktörlere karşı gelişim biyolojisi ve fizyolojisi bakımından çok farklı tepkiler gösteren bitki grubudur. Geofitler rizom, soğan ya da korm gibi toprak altı depo organında yer alan tomurcuklara sahiptirler. Bu bitkiler ticari olarak kesme çiçek üretimi ve saksı bitkisi olarak işlenmekle birlikte, dış mekanda çevre düzenlemesi ve bahçelerde kullanılmak üzere çoğaltım materyali olarak da değerlendirilmekte ve global çiçek endüstrisinde önemli bir rol oynamaktadırlar (Kamanetsky ve Okubo, 2013).

Siklamen toprakaltı yumrulu, çok yıllık gösterişli çiçeklere sahip bir bitkidir. Son yıllarda ekonomik anlamda hem ülkemizde hem de dünyada soğanlı çiçek türleri arasında önemli bir pazara sahiptir. Cyclamen cinsi geleneksel olarak Primulaceae ailesi içerisinde siniflandırılırken son yılarda Myrsinaceae ailesi içerisine alınarak yeniden taksonomik olarak sinıflandırılmıştır (Jalali ve ark., 2012; Curuk ve ark., 2015). 17. yüzyıl başlarında Batı Avrupa'ya getirilmiş ve 18. yüzyıla kadar birkaç tür kültüre alınmıştır. Bundan sonra ekonomik önemi giderek artmış ve siklamende 1slah çalışmaları başlamıştır (Mathew ve Özhatay, 2001; Amini, 2014).

Ülkemizde doğal olarak on siklamen türü yetişmektedir. Bunlardan altısı (C. pseudibericum Hildebr., $C$. trochopteranthum O. Schwarz, $C$. parviflorum Pobed., C. cilicium Boiss.e.Heldr., $C$. cilicium var. intaminatum Miekle Grey-Wilson, $C$. mirabile Hildebr.) ülkemize endemiktir (Çuruk ve ark., 2015).

Siklamen 1slahı, bitkinin döllenme biyolojisinde görülen problemler nedeniyle (kendileme depresyonu, farklı ploidy seviyeleri ve abortif embriyo oluşum gibi) klasik yöntemlerle yapılması oldukça zodur (Jalali ve ark., 2012). $\mathrm{Bu}$ nedenle, siklamen 1slahında dihaploidizasyon sıklıkla başvurulan yöntemlerden birisini oluşturmaktadır.

Haploid bitki, somatik hücrelerinde gamet hücrelerindeki kromozom sayısı kadar kromozoma sahip bitkidir (Ellialtığlu ve ark., 2001). Haploid bitkiler, doğada kendiliğinden oluşabildiği gibi farklı tekniklerin kullanılmasıyla da elde edilebilmektedir (Murovec ve Bohonec, 2012). Haploid bitkiler, normol dihaploidlerden morfolojik özellikleri bakımından biraz daha küçük ve kısır olup tohum bağlayamazlar (Emiroğlu, 1980; Abak, 1993; Dunwell, 2010; Murovec ve Bohonec, 2012; Mishra ve Goswami, 2014). Haploid bitkilerin kromozom sayısının katlanmasıyla dihaploid bitkiler elde edilir. Dihaploidizasyonla kısa sürede $\% 100$ homozigot saf hat elde edilebilmektedir. Her ne kadar doğada kendiliğinden haploid bitkiler oluşsa da bu olay oldukça nadirdir. Bu nedenle in situ ve in vitro' da haploid bitki üretimi için çeşitli teknikler kulanılmaktadır (Dunwell, 2010). In situ haploid embriyo uyartımı için, uzak akrabalar arası melezlemeler, tozlamanın geciktirilmesi, ışınlanmış (eksik veya yetersiz) polenlerle tozlama, $\mathrm{X}$ ve UV ışınları ile çeşitli kimyasalların uygulaması yapılmaktadır (Yılmaz, 2005). In vitro'da ise haploid bitkiler, temel olarak dişi 4 gamet hücresinden (gynogenesis) veya erkek gamet hücresinden (androgenesis) haploid uyartımı ile elde edilmektedir.

Gynogenesis yoluyla in vitro'da haploid bitki elde etmek için henüz tozlanmamış çiçekten alınan ovül veya ovaryum gibi kısımlar kullanılırken; androgenesis yoluyla haploid bitki elde etmek için anter ve mikrospor kullanılmaktadır. Her iki teknikte de başarı birçok biyotik ve abiyotik faktörün etkisine bağlıdır (Murovec ve Bohonec, 2012). Androgenetik yolla haploid bitki elde etmek, her zaman çok etkili bir yöntem olamamakta, bazen albino bitkilerin oluştuğu ya da donör bitkinin bu yönteme cevap vermediği durumlar da gözlenmektedir. $\mathrm{Bu}$ gibi durumlarda gynogenetik yolla (ovül ve ovaryum kültürü) haploid bitki elde etme genellikle daha sağlıklı sonuçlar verebilmektedir. Diğer taraftan, bitkinin çiçek ve meyve fizyolojisi, morfogenesisi veya meyve fizyolojisi ve biyokimyasal değişimi hakkında bilgi edinmek için ovül ve ovaryum kültürü sıklıkla başvurulan bir yöntem olmaktadır (Sita, 1997).

Gerek gynogenezis yolu ile haploid bitki elde etmek gerekse de somatik embriyogenezis yoluyla vejetatif yolla kitlesel üretim yapmak için doku kültüründe uygulanan protokoller türlere, çeşitlere ve hatta aynı çeşide ait bireylere göre farklılık göstermektedir (Tütüncü, 2017). Bu yüzden, öncelikle bitkisel materyale uygun doku kültürü protokolünün oluşturulması ve doku kültüründe etkili olan faktörlerin değerlendirilmesi gerekmektedir. $\mathrm{Bu}$ nedenle, yapılan çalışmada ele alınan türler için in vitro haploidi tekniği ve somatik embriyogenesizin en önemli aşamalarından birisi olan doku kültüründe etkili besi ortamının ve hormon konsantrasyonunun tespiti amaçlanmıştır.

\section{Materyal ve Yöntem}

\subsection{Bitkisel Materyal}

Çalışmada bitkisel materyal olarak ülkemizde doğal olarak yayiliş gösteren Cyclamen persicum ve Cyclamen pseudibericum türleri kullanılmıştır. $\mathrm{Bu}$ türlere ait genotipler 110O102'nolu “Türkiye'de Doğal Olarak Yetişen Siklamen Türlerinin Moleküler Karakterizasyonu ve in vitro muhafazası" adlı proje kapsamında daha önceden doğal ortamlarından toplanmış ve kültüre alınmış bitkilerden temin edilmiştir. Toplanan bitkiler seraya getirilerek içerisinde 1:1 torf:perlit karışımı içeren 1 litrelik saksılara dikilmiştir. Bitkilerin vejetasyon döneminde kültürel işlemler yapılarak koruma altına alınmıştır.

\subsection{Yöntem}

\subsection{1. Çiçek tomurcuklarının toplanması ve sterilizasyonu}


Bitkilerin çiçeklenme dönemlerine göre, anthesisten 2-3 gün önce çiçek tomurcukları toplanarak sterilizasyon işlemi ve ovül izolasyonu yapmak üzere laboratuvara getirilmiştir (Şekil 1). Tomurcuklar üzerinde bulunan toz, toprak gibi bulaşıklardan arındırmak için magenta kabı $(76 \times 76 \times 100 \mathrm{~mm})$ içine koyulmuş ve akan çeşme suyu altında $15-20 \mathrm{dk}$. bekletilmiştir. Daha sonra çeker ocak içine alınan örnekler aynı kap içerisine \%0.1'lik civaklorür $\left(\mathrm{HgCl}_{2}\right)$ koyulmuş ve $10 \mathrm{dk}$. bekletilmiştir. Çeker ocak içerisinde örnekler steril saf su ile 3-5 defa durulandıktan sonra temiz bir magenta kutusuna alınmıştır. Steril kabin içerisine getirilen örnekler ilk olarak \%70'lik etilalkol'de (EtOH) $1 \mathrm{dk}$. bekletilmiştir. Sonraki aşamada, eksplantlar cam behere aktarılmış ve 1-2 damla Tween-20 içeren \%25'lik ticari sodyumhipoklorit (\%4.5 aktif klorin, v/v, $\mathrm{NaOCl}$, Domestos $\left.{ }^{\circledR}\right)$ içerisinde $10 \mathrm{dk}$. bekletilmiştir. Örnekler köpüklerinden arınıncaya kadar steril saf su ile durulanmıştır. Sterilizasyon aşaması biten çiçek tomurcukları ovüller izole edilene kadar saf su içerisinde bekletilmiştir.

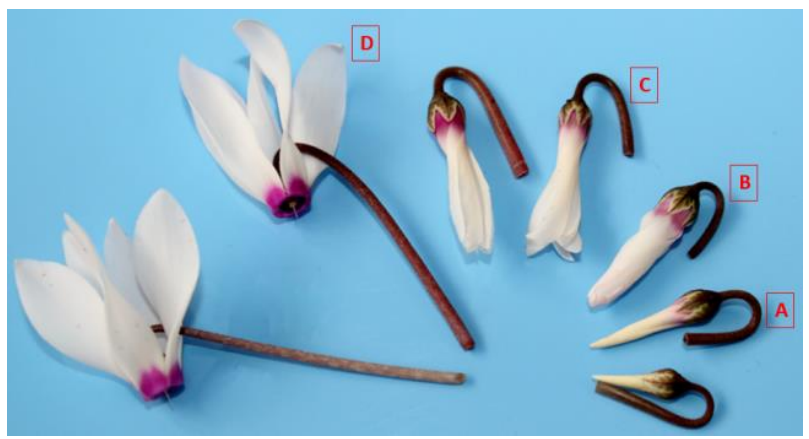

Şekil 1. Siklamen'de çiçek açımı aşamaları (A: Çiçek tomurcuğu, B: Çiçek tomurcuğu balon aşaması, $\mathbf{C}$ : Çiçek açımı (Anthesis), D: Tam çiçek açımı)

\subsection{2. Çiçek tomurcuklarından ovüllerin izolasyonu}

Çiçek tomurcukları yüzey sterilizasyonu yapıldıktan sonra ovül izolasyonu aşamasına geçilmiştir (Şekil 2 (A)). Ovülleri açığa çıkartmak amacıyla öncelikle petallerin birleşim noktaları altından başlayarak tomurcuğun etrafi boyunca bistüri ile kesilerek uzaklaştırılmıştır. (Şekil 2 (B)). Petaller uzaklaştırıldıktan sonra aynı işlem tekrarlanarak taç yaprakların ve daha iç kısımda bulunan anterler uzaklaştırılarak ovaryum açığa çıkartılmıştır (Şekil 2 (C)). Son olarak ovaryum kilıfi da dikkatlice uzaklaştırılmış ve ovüller görünür hale getirilmiştir. (Şekil 2 (D)). Sonraki aşamada ovüller küt uçlu diseksiyon iğnesi kullanılarak zarar verilmeden tek tek $5 \mathrm{X}$ büyütmeli stereo binoküler mikroskop (Leitz, Weitzlar, Germany) altında çıkartılarak kültür ortamlarına koyulmuştur.

\subsection{3. Çalı̧̧mada kullanılan besi ortamları ve hormonlar}

Çalışmada embriyo uyartımının optimizasyonu amaciyla her iki türde de 1/2MS (Murashige and Skoog, 1962) ve B5 (Gamborg ve ark., 1968) besi ortamları (Sigma-Aldrich, St. Louis, USA), temel besi ortamları olarak kullanılmıştır.

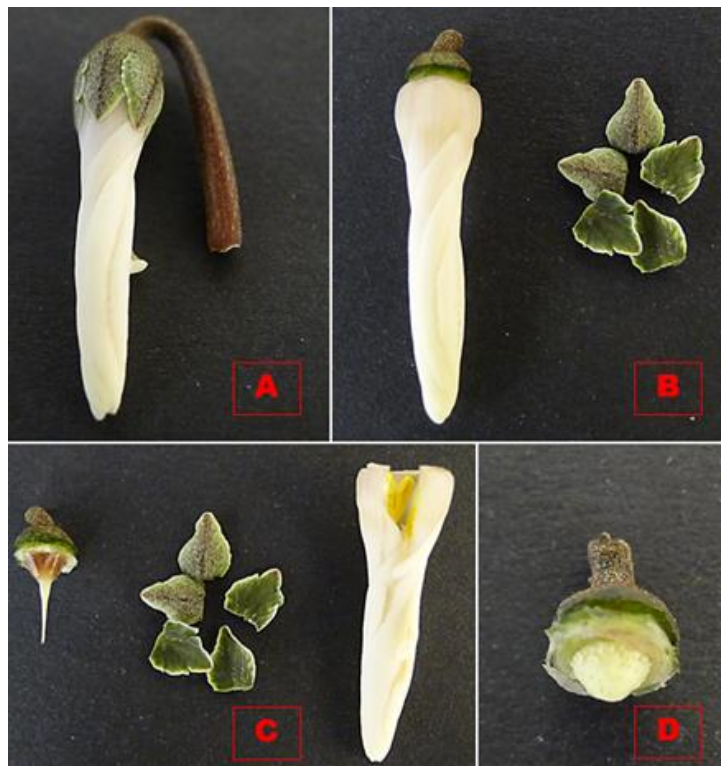

Şekil 2. Siklamende çiçek tomurcuklarından ovüllerin izolasyon aşamaları. (A: Çiçek tomurcuğu genel görünümü, B: Petallerin uzaklaştırılması, C: Taç yaprakların ve anterlerin uzaklaştııılması, D: Ovaryum kılıfının uzaklaştıılarak ovüllerin ortaya çıkarılması.)

Denemede kullanılan besi yerlerinin pH's1 otoklavlanmadan $\left(20 \mathrm{dk} .121{ }^{\circ} \mathrm{C}^{\prime} \mathrm{de}\right)$ önce $5.7^{\prime}$ ye ayarlanmıştır. Çalışmada ilk olarak ovüller 2,4-D (0.5$1.0-1.5$ ve $\left.2.0 \mathrm{mg} \mathrm{L}^{-1}\right)$ ve $2 \mathrm{iP}\left(0.1-0.3-0.5\right.$ ve $\left.0.8 \mathrm{mg} \mathrm{L}^{-1}\right)$ büyüme düzenleyicilerinin kombinasyonlarının bulunduğu $1 / 2 \mathrm{MS}$ ve B5 katı kallus uyartım ortamlarına aktarılmıştır. Eksplantlar, 16 hafta boyunca karanlıkta 23-25 ${ }^{\circ} \mathrm{C}^{\prime}$ de kültüre alınmıştır. 16 hafta sonra elde edilen kalluslar hormon içermeyen $1 / 2 \mathrm{MS}$ ve $\mathrm{B} 5$ farklılaştırma ortamlarına transfer edilerek büyütme odası koşullarında (16 saat fotoperyodisite, beyaz florasan 1şık, 1şık şiddeti: $75 \mu \mathrm{mol} \mathrm{m} \mathrm{m}^{-2} \mathrm{~s}^{-1}$, sıcaklık: $24 \pm 1$ $\left.{ }^{\circ} \mathrm{C}\right)$ kültüre alınarak gelişimleri gözlenmiştir.

\subsubsection{Deneme plant ve istatistiksel analizler}

Çalışmada 2 tür, 2 ortam ve 16 farklı hormon konsantrasyonu ile hormon içermeyen kontrol ortamı kullanılmıştır. Deneme 4 tekerrürlü $(4$ petri) her tekerrürde (her petride) 10 eksplant olacak şekilde faktöriyel düzende tesadüf blokları deneme desenine göre yürütülmüştür. Elde edilen yüzde değerler hesaplandıktan sonra açı transformasyonu uygulanmış, verilerin analizi JMP (versiyon 5.01) paket programı ile yapılmışır. Ortalamaların önem seviyeleri LSD $(\mathrm{p}<0.01)$ testi ile karşılaştırılmıştır. 


\section{Bulgular}

\subsection{Eksplantlardan kallus gelişimi}

Cyclamen persicum türünde iki farklı besi ortamı kullanılmış ve istatistiki açıdan kullanılan ortamların rejenerasyona etkisi önemsiz $(p>0.05) \quad$ (değerler istatistiki açıdan önemli bulunmadığından verilmemiştir) bulunurken ortam-hormon interaksiyonu istatistiki açıdan önemli bulunmuştur $(\mathrm{p}<0.01)$ (Çizelge 1). Eksplantlardan en iyi kallus gelişimi $\% 70$ rejenerasyon oraniyla $1.5 \mathrm{mg} \mathrm{L}^{-1} 2,4-\mathrm{D}$ ve $0.5 \mathrm{mg} \mathrm{L}^{-1}$ 2iP içeren B5 ortamında olmuştur. Genel olarak yüksek konsantrasyonda oksin ve düşük konsantrasyonda sitokinin içeren B5 ortamlarında kallus oluşum oranının daha yüksek olduğu bulunmuştur (Çizelge 1).

Çizelge 1. Cyclamen persicum türünde besi ortamı-hormon interaksiyonunun kallus gelişim oranına etkisi

\begin{tabular}{|c|c|c|}
\hline Ortam*Hormon Konsantrasyonu & $\begin{array}{l}\text { Kallus Gelişim Oranı } \\
(\%)\end{array}$ & $\mathrm{LSD}_{\mathrm{Ortam} * \text { hormon }}$ \\
\hline $\mathrm{B} 5+1.5 \mathrm{mg} \mathrm{L}^{-1} 2,4-\mathrm{D}+0.5 \mathrm{mg} \mathrm{L}^{-1} 2 \mathrm{iP}$ & $70.00 \mathrm{a}(60.24)$ & \multirow{21}{*}{$22.29 *$} \\
\hline $\mathrm{B} 5+2.0 \mathrm{mg} \mathrm{L}^{-1} 2,4-\mathrm{D}+0.3 \mathrm{mg} \mathrm{L}^{-1} 2 \mathrm{iP}$ & $64.00 \mathrm{ab}(53.22)$ & \\
\hline $\mathrm{B} 5+1.0 \mathrm{mg} \mathrm{L}^{-1} 2,4-\mathrm{D}+0.8 \mathrm{mg} \mathrm{L}^{-1} 2 \mathrm{iP}$ & $44.00 \mathrm{a}-\mathrm{c}(41.31)$ & \\
\hline $\mathrm{B} 5+2.0 \mathrm{mg} \mathrm{L}^{-1} 2,4-\mathrm{D}+0.1 \mathrm{mg} \mathrm{L}^{-1} 2 \mathrm{iP}$ & 44.00 a-c (40.84) & \\
\hline $1 / 2 \mathrm{MS}+1.0 \mathrm{mg} \mathrm{L}^{-1} 2,4-\mathrm{D}+0.5 \mathrm{mg} \mathrm{L}^{-1} 2 \mathrm{iP}$ & $42.00 \mathrm{a}-\mathrm{d}(37.82)$ & \\
\hline $\mathrm{B} 5+1.5 \mathrm{mg} \mathrm{L}^{-1} 2,4-\mathrm{D}+0.1 \mathrm{mg} \mathrm{L}^{-1} 2 \mathrm{iP}$ & 40.00 b-e (33.39) & \\
\hline $\mathrm{B} 5+2.0 \mathrm{mg} \mathrm{L}^{-1} 2,4-\mathrm{D}+0.8 \mathrm{mg} \mathrm{L}^{-1} 2 \mathrm{iP}$ & $30.00 \mathrm{c}-\mathrm{f}(27.60)$ & \\
\hline $1 / 2 \mathrm{MS}+1.0 \mathrm{mg} \mathrm{L}^{-1} 2,4-\mathrm{D}+0.1 \mathrm{mg} \mathrm{L}^{-1} 2 \mathrm{iP}$ & $30.00 \mathrm{c}-\mathrm{f}(27.40)$ & \\
\hline $1 / 2 \mathrm{MS}+0.5 \mathrm{mg} \mathrm{L}^{-1} 2,4-\mathrm{D}+0.3 \mathrm{mg} \mathrm{L}^{-1} 2 \mathrm{iP}$ & $28.00 \mathrm{c}-\mathrm{f}(26.24)$ & \\
\hline $1 / 2 \mathrm{MS}+1.0 \mathrm{mg} \mathrm{L}^{-1} 2,4-\mathrm{D}+0.3 \mathrm{mg} \mathrm{L}^{-1} 2 \mathrm{iP}$ & $24.00 \mathrm{c}-\mathrm{f}(25.99)$ & \\
\hline $1 / 2 \mathrm{MS}+1.5 \mathrm{mg} \mathrm{L}^{-1} 2,4-\mathrm{D}+0.5 \mathrm{mg} \mathrm{L}^{-1} 2 \mathrm{iP}$ & $22.00 \mathrm{c}-\mathrm{g}(24.60)$ & \\
\hline $\mathrm{B} 5+1.5 \mathrm{mg} \mathrm{L}^{-1} 2,4-\mathrm{D}+0.3 \mathrm{mg} \mathrm{L}^{-1} 2 \mathrm{iP}$ & $20.00 \mathrm{c}-\mathrm{f}(23.11)$ & \\
\hline $1 / 2 \mathrm{MS}+1.5 \mathrm{mg} \mathrm{L}^{-1} 2,4-\mathrm{D}+0.8 \mathrm{mg} \mathrm{L}^{-1} 2 \mathrm{iP}$ & $20.00 \mathrm{c}-\mathrm{g}(22.95)$ & \\
\hline $\mathrm{B} 5+2.0 \mathrm{mg} \mathrm{L}^{-1} 2,4-\mathrm{D}+0.5 \mathrm{mg} \mathrm{L}^{-1} 2 \mathrm{iP}$ & $18.00 \mathrm{c}-\mathrm{g}(19.55)$ & \\
\hline $1 / 2 \mathrm{MS}+2.0 \mathrm{mg} \mathrm{L}^{-1} 2,4-\mathrm{D}+0.1 \mathrm{mg} \mathrm{L}^{-1} 2 \mathrm{iP}$ & $18.00 \mathrm{~d}-\mathrm{g}(17.44)$ & \\
\hline $1 / 2 \mathrm{MS}+1.0 \mathrm{mg} \mathrm{L}^{-1} 2,4-\mathrm{D}+0.8 \mathrm{mg} \mathrm{L}^{-1} 2 \mathrm{iP}$ & $12.00 \mathrm{~d}-\mathrm{g}(16.33)$ & \\
\hline $1 / 2 \mathrm{MS}+1.5 \mathrm{mg} \mathrm{L}^{-1} 2,4-\mathrm{D}+0.1 \mathrm{mg} \mathrm{L}^{-1} 2 \mathrm{iP}$ & $12.00 \mathrm{~d}-\mathrm{g}(16.04)$ & \\
\hline $1 / 2 \mathrm{MS}+0.5 \mathrm{mg} \mathrm{L}^{-1} 2,4-\mathrm{D}+0.5 \mathrm{mg} \mathrm{L}^{-1} 2 \mathrm{iP}$ & $12.00 \mathrm{e}-\mathrm{g}(13.28)$ & \\
\hline $1 / 2 \mathrm{MS}+2.0 \mathrm{mg} \mathrm{L}^{-1} 2,4-\mathrm{D}+0.3 \mathrm{mg} \mathrm{L}^{-1} 2 \mathrm{iP}$ & $10.00 \mathrm{e}-\mathrm{g}(13.08)$ & \\
\hline $1 / 2 \mathrm{MS}+1.5 \mathrm{mg} \mathrm{L}^{-1} 2,4-\mathrm{D}+0.3 \mathrm{mg} \mathrm{L}^{-1} 2 \mathrm{iP}$ & $10.00 \mathrm{e}-\mathrm{g}(12.55)$ & \\
\hline $\mathrm{B} 5+0.5 \mathrm{mg} \mathrm{L}^{-1} 2,4-\mathrm{D}+0.8 \mathrm{mg} \mathrm{L}^{-1} 2 \mathrm{iP}$ & $10.00 \mathrm{e}-\mathrm{g}(12.55)$ & \\
\hline
\end{tabular}

Açı transformasyonu sonrasında elde edilmiş değerler parantez içinde verilmiştir. Ortalamalar arasındaki farklılıklar harflerle gösterilmiştir. ${ }^{*} \mathrm{p}<0.01$

Çalışma kapsamında ayrıca oluşan kallusların morfolojik yapıları gözlemlenmiştir. C. persicum türüne ait ovül örnekleri her iki ortamda da değișen oranlarda rejenere olmuş ve farklı kallus yapılarını meydana getirmiştir. Yapılan incelemelerde $1 / 2 \mathrm{MS}$ ortamında gelişen kallusların dokusunun yumuşak, kallus renk koyuluğunun orta koyulukta ya da açık olduğu, kallus renginin ise kahverengi ve sarı tonları arasında olduğu gözlenmiştir (Şekil 3). Ayrıca 1/2MS besiyerinde oluşan kallusların B5 ortamında oluşan kalluslara göre daha kırılgan yapıya sahip oldukları gözlenmiştir. $C$. persicum türünden izole edilen ve B5 ortamına transfer edilen ovüllerden gelişen kallusların incelenmesinde; kallus dokusunun sert özellikle bazı eksplantlarda çok sert olduğu, kallus renginin ise rejenerasyonun ilk aşamalarında şeffaf sonrasında ise koyu kahverengi hatta siyah renge döndüğü gözlenmiştir (Şekil 4).
Ayrıca B5 besiyerinde oluşan kallusların yapısının $1 / 2 \mathrm{MS}$ ortamında oluşan kalluslara göre daha kompakt ve sert yapıya sahip oldukları gözlenmiştir.

Denemede kullanilan ortam-hormon intereaksiyonunun Cyclamen pseudibericum ovül eksplantlarında kallus gelişim oranına etkisi Çizelge 2'de verilmiştir.

Çalışmada, istatistiksel açıdan kullanılan besi ortamı ve içerdiği farklı konsantrasyonlardaki hormonların içeriği interaksiyonunun $C$. pseudibericum'un ovül eksplantlarından kallus rejenerasyonuna etkisi önemli bulunmuştur $(p<0.01)$. En iyi kallus gelișim oranı $\% 48$ ile $1 \mathrm{mg} \mathrm{L}^{-1} 2,4-\mathrm{D}$ ve $0.3 \mathrm{mg} \mathrm{L}^{-1} 2 \mathrm{PP}$ içeren B5 besi ortamından elde edilmiştir. Bu ortamı \%38'lik kallus gelişim oranı ile hormon kombinasyonunu $2 \mathrm{mg} \mathrm{L}^{-1} 2,4-$ $\mathrm{D}$ ve $0.8 \mathrm{mg} \mathrm{L}^{-1} 2 \mathrm{iP}$ içeren $1 / 2 \mathrm{MS}$ besi ortamı takip etmiştir. 
Çizelge 2. Cyclamen pseudibericum türünde besi ortamı-hormon interaksiyonu ve kallus gelişim oranına etkisi

\begin{tabular}{|c|c|c|}
\hline Ortam*Hormon Konsantrasyonu & $\begin{array}{c}\text { Kallus Gelişim Oranı } \\
(\%)\end{array}$ & $\mathrm{LSD}_{\text {Ortam*hormon }}$ \\
\hline $\mathrm{B} 5+1.0 \mathrm{mg} \mathrm{L}^{-1} 2,4-\mathrm{D}+0.3 \mathrm{mg} \mathrm{L}^{-1} 2 \mathrm{iP}$ & $48.00 \mathrm{a}(43.67)$ & \\
\hline $1 / 2 \mathrm{MS}+2.0 \mathrm{mg} \mathrm{L}^{-1} 2,4-\mathrm{D}+0.5 \mathrm{mg} \mathrm{L}^{-1} 2 \mathrm{iP}$ & $38.00 \mathrm{ab}(34.84)$ & \\
\hline $\mathrm{B} 5+1.5 \mathrm{mg} \mathrm{L}^{-1} 2,4-\mathrm{D}+0.5 \mathrm{mg} \mathrm{L}^{-1} 2 \mathrm{iP}$ & $36.00 \mathrm{a}-\mathrm{c}(33.04)$ & \\
\hline $\mathrm{B} 5+1.5 \mathrm{mg} \mathrm{L}^{-1} 2,4-\mathrm{D}+0.3 \mathrm{mg} \mathrm{L}^{-1} 2 \mathrm{iP}$ & $32.00 \mathrm{a}-\mathrm{c}(31.28)$ & \\
\hline $\mathrm{B} 5+1 \mathrm{mg} \mathrm{L}^{-1} 2,4-\mathrm{D}+0.1 \mathrm{mg} \mathrm{L}^{-1} 2 \mathrm{iP}$ & $32.00 \mathrm{a}-\mathrm{d}(28.15)$ & \\
\hline $\mathrm{B} 5+2.0 \mathrm{mg} \mathrm{L}^{-1} 2,4-\mathrm{D}+0.1 \mathrm{mg} \mathrm{L}^{-1} 2 \mathrm{iP}$ & 30.00 a-d (27.42) & \\
\hline $1 / 2 \mathrm{MS}+1.5 \mathrm{mg} \mathrm{L}^{-1} 2,4-\mathrm{D}+0.5 \mathrm{mg} \mathrm{L}^{-1} 2 \mathrm{iP}$ & 26.00 a-d (26.40) & \\
\hline $1 / 2 \mathrm{MS}+1.5 \mathrm{mg} \mathrm{L}^{-1} 2,4-\mathrm{D}+0.3 \mathrm{mg} \mathrm{L}^{-1} 2 \mathrm{iP}$ & 24.00 a-d (25.97) & \\
\hline $\mathrm{B} 5+1.5 \mathrm{mg} \mathrm{L}^{-1} 2,4-\mathrm{D}+0.8 \mathrm{mg} \mathrm{L}^{-1} 2 \mathrm{iP}$ & $22.00 \mathrm{~b}-\mathrm{e}(25.11)$ & \\
\hline $1 / 2 \mathrm{MS}+1.5 \mathrm{mg} \mathrm{L}^{-1} 2,4-\mathrm{D}+0.8 \mathrm{mg} \mathrm{L}^{-1} 2 \mathrm{iP}$ & $22.00 \mathrm{~b}-\mathrm{e}(24.69)$ & \\
\hline $\mathrm{B} 5+2.0 \mathrm{mg} \mathrm{L}^{-1} 2,4-\mathrm{D}+0.3 \mathrm{mg} \mathrm{L}^{-1} 2 \mathrm{iP}$ & $22.00 \mathrm{~b}-\mathrm{e}(22.33)$ & $18.49^{*}$ \\
\hline $1 / 2 \mathrm{MS}+1.0 \mathrm{mg} \mathrm{L}^{-1} 2,4-\mathrm{D}+0.3 \mathrm{mg} \mathrm{L}^{-1} 2 \mathrm{iP}$ & $16.00 \mathrm{~b}-\mathrm{f}(18.59)$ & \\
\hline $\mathrm{B} 5+0.5 \mathrm{mg} \mathrm{L}^{-1} 2,4-\mathrm{D}+0.3 \mathrm{mg} \mathrm{L}^{-1} 2 \mathrm{iP}$ & $12.00 \mathrm{c}-\mathrm{g}(15.64)$ & \\
\hline $1 / 2 \mathrm{MS}+1.0 \mathrm{mg} \mathrm{L}^{-1} 2,4-\mathrm{D}+0.5 \mathrm{mg} \mathrm{L}^{-1} 2 \mathrm{iP}$ & $8.00 \mathrm{~d}-\mathrm{g}(12.68)$ & \\
\hline $\mathrm{B} 5+0.5 \mathrm{mg} \mathrm{L}^{-1} 2,4-\mathrm{D}+0.5 \mathrm{mg} \mathrm{L}^{-1} 2 \mathrm{iP}$ & $10.00 \mathrm{~d}-\mathrm{g}(11.95)$ & \\
\hline $1 / 2 \mathrm{MS}+2.0 \mathrm{mg} \mathrm{L}^{-1} 2,4-\mathrm{D}+0.3 \mathrm{mg} \mathrm{L}^{-1} 2 \mathrm{iP}$ & $8.00 \mathrm{~d}-\mathrm{g}(10.62)$ & \\
\hline $\mathrm{B} 5+1.5 \mathrm{mg} \mathrm{L}^{-1} 2,4-\mathrm{D}+0.1 \mathrm{mg} \mathrm{L}^{-1} 2 \mathrm{iP}$ & $4.00 \mathrm{e}-\mathrm{g}(7.37)$ & \\
\hline $\mathrm{B} 5+1.0 \mathrm{mg} \mathrm{L}^{-1} 2,4-\mathrm{D}+0.8 \mathrm{mg} \mathrm{L}^{-1} 2 \mathrm{iP}$ & $6.00 \mathrm{e}-\mathrm{g}(6.64)$ & \\
\hline $1 / 2 \mathrm{MS}+2.0 \mathrm{mg} \mathrm{L}^{-1} 2,4-\mathrm{D}+0.8 \mathrm{mg} \mathrm{L}^{-1} 2 \mathrm{iP}$ & $4.00 \mathrm{f}-\mathrm{g}(3.68)$ & \\
\hline $1 / 2 \mathrm{MS}+0.5 \mathrm{mg} \mathrm{L}^{-1} 2,4-\mathrm{D}+0.5 \mathrm{mg} \mathrm{L}^{-1} 2 \mathrm{iP}$ & $2.00 \mathrm{f}-\mathrm{g}(3.68)$ & \\
\hline $1 / 2 \mathrm{MS}+1.0 \mathrm{mg} \mathrm{L}^{-1} 2,4-\mathrm{D}+0.1 \mathrm{mg} \mathrm{L}^{-1} 2 \mathrm{iP}$ & $2.00 \mathrm{f}-\mathrm{g}(3.68)$ & \\
\hline $\mathrm{B} 5+0.5 \mathrm{mg} \mathrm{L}^{-1} 2,4-\mathrm{D}+0.1 \mathrm{mg} \mathrm{L}^{-1} 2 \mathrm{iP}$ & $2.00 \mathrm{f}-\mathrm{g}(3.68)$ & \\
\hline
\end{tabular}

Açı transformasyonu sonrasında elde edilmiş değerler parantez içinde verilmiştir. Ortalamalar arasındaki farkl1lıklar harflerle gösterilmiştir. * $\mathrm{p}<0.01$

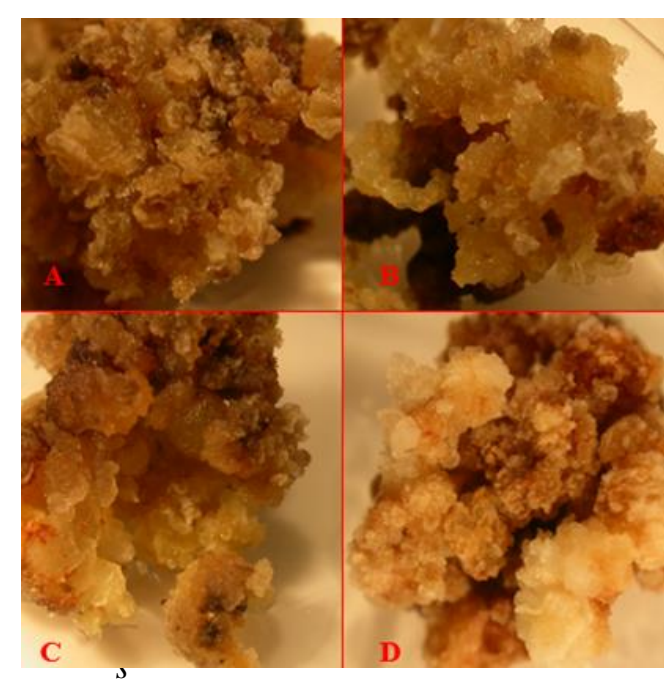

icum türünde farklı hormon konsantrasyonlarına sahip $1 / 2 \mathrm{MS}$ besiyerinde gelişen kallus yapıları (A: 1 $\mathrm{mg} \mathrm{L}^{-1} 2,4-\mathrm{D}+0.5 \mathrm{mg} \mathrm{L}^{-1} 2 \mathrm{PP}, \mathrm{B}: 1 \mathrm{mg} \mathrm{L}^{-1}$ 2,4-D + $0.1 \mathrm{mg} \mathrm{L}^{-1} 2 \mathrm{PP}, \mathrm{C}: 0.5 \mathrm{mg} \mathrm{L}^{-1} 2,4-\mathrm{D}$ $+0.3 \mathrm{mg} \mathrm{L}^{-1}$ 2iP, D: $1 \mathrm{mg} \mathrm{L}^{-1} 2,4-\mathrm{D}+0.3$ $\left.\mathrm{mg} \mathrm{L}^{-1} 2 \mathrm{iP}\right)$.

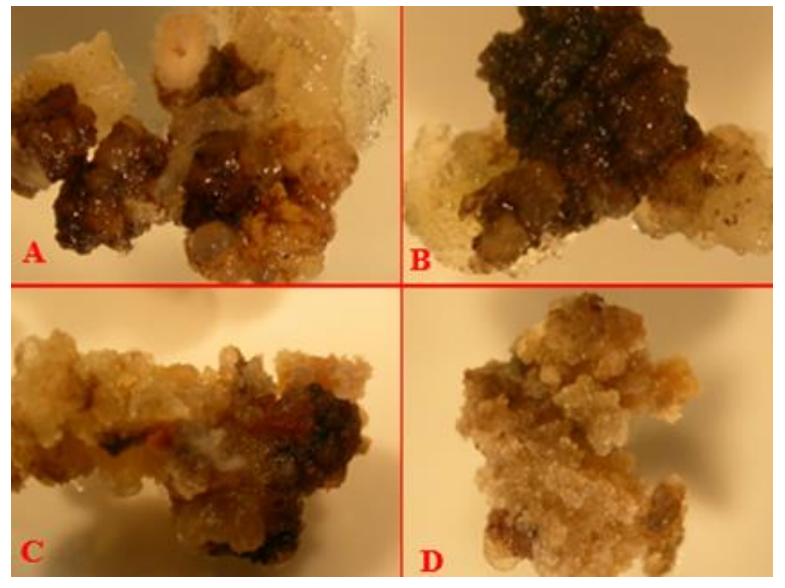

Şekil 4. C. persicum'da farklı hormon konsantrasyonları içeren B5 ortamında gelişen kallus yapıları (A: $1.5 \mathrm{mg} \mathrm{L}^{-1} 2,4-$ $\mathrm{D}+0.5 \mathrm{mg} \mathrm{L}^{-1} 2 \mathrm{PP}, \mathbf{B}: 2 \mathrm{mg} \mathrm{L}^{-1} 2,4-\mathrm{D}+0.3$ $\mathrm{mg} \mathrm{L}^{-1} 2 \mathrm{iP}, \mathbf{C}$ : $1.5 \mathrm{mg} \mathrm{L}^{-1} 2,4-\mathrm{D}+0.1 \mathrm{mg} \mathrm{L}^{-1}$ 2iP, D: $2 \mathrm{mg} \mathrm{L}^{-1} 2,4-\mathrm{D}+0.1 \mathrm{mg} \mathrm{L}^{-1} 2 \mathrm{iP}$ ) 
C. pseudibericum türüne ait ovül örnekleri her iki ortamda da değişen oranlarda rejenere olmuş ve farklı kallus yapıları meydana getirmiştir. Yapılan mikroskobik incelemelerde izole edilen ovül yapıları başlangıçta normal şekilde şişme ve kallusa dönüşme eğilimi göstermiştir. Ancak, zamanla her iki besi ortamında da gelişen kallus dokusu giderek sert ve kırılgan bir yapı almıştır. Bu süreç içerisinde kalluslar hacimce büyümüş ve embriyoya benzer yapılar göstermeye başlamıştır.

Diğer taraftan başlangıçta şeffaf olan kallus renginin gittikçe koyulaştığı ve siyahlaştığı gözlenmiştir. Bu şekilde siyahlaşan, sert ve çok kırılgan bir hal alan kallus yapılarının alt kültür işlemleri devam ettirilmiş ancak, embriyo benzeri yapı oluşturan kallusların gelişim sürecinin sona erdiği kanaatine varılmıștır.

C. pseudibericum türüne ait ovül eksplantlarından kallus gelişimi ve sonrasında kallus renklerinin siyahlaşarak gelişimini tamamlaması ile ilgili görüntüler Şekil 5'de verilmiştir.

\section{2. embriyo uyartım oranı}

Çalışmada ilk olarak ovüller 2,4-D (0.5-1.0-1.5 ve $\left.2.0 \mathrm{mg} \mathrm{L}^{-1}\right), 2 \mathrm{iP}\left(0.1-0.3-0.5\right.$ ve $\left.0.8 \mathrm{mg} \mathrm{L}^{-1}\right)$ büyüme düzenleyicilerinin kombinasyonlarının bulunduğu $1 / 2 \mathrm{MS}$ ve B5 ortamlarını aktarılmış ve 16 hafta boyunca karanlıkta $23-25^{\circ} \mathrm{C}$ 'de kültüre alınmıştır.

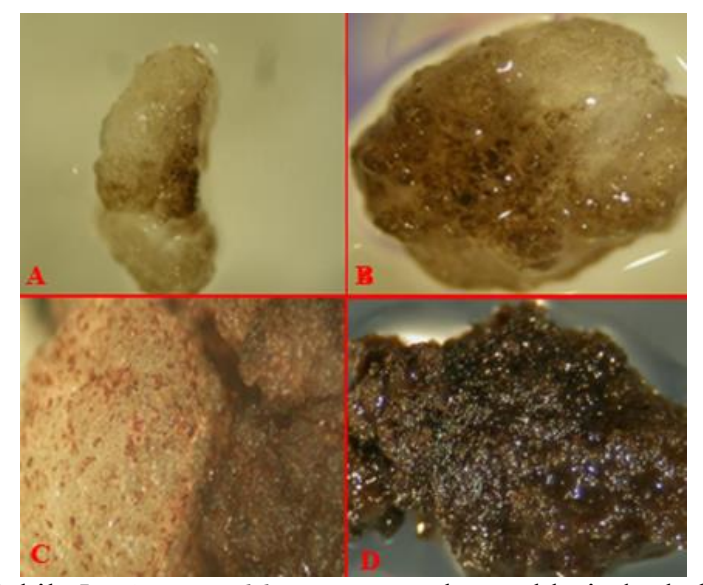

Şekil 5. C. pseudibericum ovül örneklerinde kallus gelişim aşamaları (A: Ovüllerin şişmesi, B: Kallus oluşumu, C: Embriyo benzeri yapıların oluşumu, D: Kallusların siyahlaşıp gelişiminin tamamlanmasi)

16 hafta sonra elde edilen kalluslar hormon içermeyen $1 / 2 \mathrm{MS}$ ve B5 farklılaştırma ortamlarına transfer edilmiştir. Yapılan gözlemler sonucunda meydana gelen embriyojenik kalluslar, her 4 haftada bir hormon içermeyen besiyerlerinde alt kültüre alınmıştır. Embriyojenik kalluslar gelişmeye başladığında, büyütme odası koşullarında (16 saat fotoperyodisite, $25 \pm 1{ }^{\circ} \mathrm{C}$ ) kültüre alınarak gelişimleri gözlenmiştir. Sonraki aşama da kallus başına oluşan embriyo sayısı gözlenerek embriyo uyartım oranı hesaplanmış ve sonuçlar istatistiki olarak değerlendirilmiştir. Sonraki aşama da kallus başına oluşan embriyo sayısı gözlenerek embriyo uyartım oranı hesaplanmış ve sonuçlar istatistiki olarak değerlendirilmiştir. $C$. persicum türünde embriyo uyartımı gerçekleşirken, $C$. pseudibericum türünde oluşan kallus yapıları siyahlaşmış ve embriyo uyartımı gerçekleşmemiştir. $C$. persicum türünde embriyo uyartımına kullanılan besi ortamlarının etkisi istatistiki açıdan önemli bulunmazken, hormon ve besi ortamı hormon interaksiyonu önemli bulunmuştur. En yüksek embriyo uyartımı $1.5 \mathrm{mg} \mathrm{L}^{-1} 2,4-\mathrm{D}$ ve $0.8 \mathrm{mg} \mathrm{L}^{-1} 2$ iP içeren besi yerinde ortalama $\% 30$ oranında gerçekleşmiştir, bunu $1.5 \mathrm{mg} \mathrm{L}^{-1} 2,4-\mathrm{D}+0.1 \mathrm{mg} \mathrm{L}^{-1} 2 \mathrm{iP}\left(\%\right.$ 20) ve $2.0 \mathrm{mg} \mathrm{L}^{-1}$ 2,4-D + $0.8 \mathrm{mg} \mathrm{L}^{-1} 2 \mathrm{iP}(\% 16.8)$ takip etmiştir (Çizelge $3)$.

Embriyo uyartımının gerçekleştiği 12 besi ortamıhormon kombinasyonundan 8'i B5 ortamının kullanıldığ1 kültür ortamları olarak bulunmuştur. $\mathrm{Bu}$ sonuçlar Cyclamen persicum türünde rejenere olan kallusların farklılaşmasında ve embriyo uyartımında B5 besi ortamının daha etkili olduğunu düşündürmektedir.

Çalışmada, istatistiksel açıdan kullanılan besi ortamı ve içerdiği farklı hormon konsantrasyonlarının interaksiyonu, $C$. persicum örneklerinde embriyo uyartımı üzerine etkisi önemli bulunmuştur $(\mathrm{p}<0.01)$. $C$. persicum ve $C$. pseudibericum türlerinden alınan ovül eksplantlarının rejenerasyonunda her ne kadar B5 ortamı ön plana çıkmış olsa da embriyo uyartımında $1 / 2 \mathrm{MS}$ besi ortaminda rejenere olan kalluslardan embriyo uyartımı oranı daha yüksektir. Bu kapsamda $1.5 \mathrm{mg} \mathrm{L}^{-1}$ 2,4-D ve $0.8 \mathrm{mg} \mathrm{L}^{-1} 2 \mathrm{iP}$ içeren $1 / 2 \mathrm{MS}$ ortamında oluşan kalluslarda $\% 55$ oranda en yüksek embriyo uyartımı gerçekleşmiştir. Bunu sırasıyla \%33.75 oranı ile $2 \mathrm{mg} \mathrm{L}^{-}$ ${ }_{1}^{1} 2,4-\mathrm{D}$ ve $0.8 \mathrm{mg} \mathrm{L}^{-1} 2 \mathrm{P}$ içeren B5 ortamı, \%32.5 oranıyla $1.5 \mathrm{mg} \mathrm{L}^{-1} 2,4$-D ve $0.3 \mathrm{mg} \mathrm{L}^{-1} 2 \mathrm{PP}$ içeren $1 / 2 \mathrm{MS}$ ortamı ve $\% 22.5$ oran ile $1.5 \mathrm{mg} \mathrm{L}^{-1} 2,4-\mathrm{D}$ ve $0.1 \mathrm{mg} \mathrm{L}^{-1}$ 2iP içeren B5 ortamı takip etmiştir. C. persicum türünde, embriyo uyartımı gerçekleştikten sonra oluşan embriyoya benzer yapılar, gelişerek normal bir embriyonun gelişim sürecindeki aşamaları takip etmiş̧ir (Şekil 6).

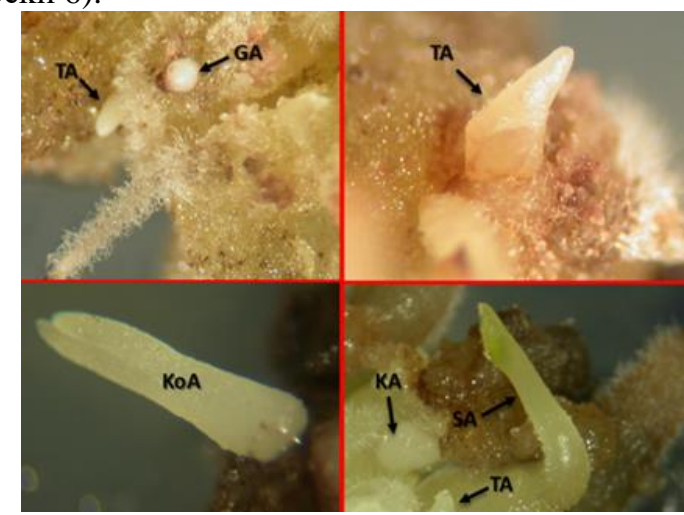

Şekil 6. C. persicum türünde embriyo aşamaları (GA: Globüler aşama, TA: Torpedo aşaması, KA: Kalp aşaması, KoA: Kotiledon aşaması, SA: Sürgün aşaması) 
Çizelge 3. Cyclamen persicum türünde besi ortamı hormon interaksiyonunun embriyo uyartım oranına etkisi

\begin{tabular}{|c|c|c|}
\hline Ortam*Hormon Konsantrasyonu & $\begin{array}{c}\text { Embriyo Uyartımı } \\
(\%)\end{array}$ & LSD $_{\text {Ortam*hormon }}$ \\
\hline $1 / 2 \mathrm{MS}+1.5 \mathrm{mg} \mathrm{L}^{-1} 2,4-\mathrm{D}+0.8 \mathrm{mg} \mathrm{L}^{-1} 2 \mathrm{iP}$ & 55.0 a (45.24) & \\
\hline $\mathrm{B} 5+2.0 \mathrm{mg} \mathrm{L}^{-1} 2,4-\mathrm{D}+0.8 \mathrm{mg} \mathrm{L}^{-1} 2 \mathrm{iP}$ & $33.75 \mathrm{a}-\mathrm{b}(31.75)$ & \\
\hline $1 / 2 \mathrm{MS}+1.5 \mathrm{mg} \mathrm{L}^{-1} 2,4-\mathrm{D}+0.3 \mathrm{mg} \mathrm{L}^{-1} 2 \mathrm{iP}$ & $32.5 \mathrm{a}-\mathrm{b}(31.05)$ & \\
\hline $\mathrm{B} 5+1.5 \mathrm{mg} \mathrm{L}^{-1} 2,4-\mathrm{D}+0.1 \mathrm{mg} \mathrm{L}^{-1} 2 \mathrm{iP}$ & $22.5 \mathrm{~b}-\mathrm{c}(21.55)$ & \\
\hline $1 / 2 \mathrm{MS}+1.5 \mathrm{mg} \mathrm{L}^{-1} 2,4-\mathrm{D}+0.1 \mathrm{mg} \mathrm{L}^{-1} 2 \mathrm{iP}$ & $17.5 \mathrm{~b}-\mathrm{d}(14.94)$ & \\
\hline $1 / 2 \mathrm{MS}+1.5 \mathrm{mg} \mathrm{L}^{-1} 2,4-\mathrm{D}+0.5 \mathrm{mg} \mathrm{L}^{-1} 2 \mathrm{iP}$ & $17.5 \mathrm{~b}-\mathrm{d}(14.94)$ & $18.63^{*}$ \\
\hline $\mathrm{B} 5+2.0 \mathrm{mg} \mathrm{L}^{-1} 2,4-\mathrm{D}+0.5 \mathrm{mg} \mathrm{L}^{-1} 2 \mathrm{iP}$ & $10.0 \mathrm{~b}-\mathrm{d}(13.41)$ & \\
\hline $\mathrm{B} 5+2.0 \mathrm{mg} \mathrm{L}^{-1} 2,4-\mathrm{D}+0.3 \mathrm{mg} \mathrm{L}^{-1} 2 \mathrm{iP}$ & $5.0 \mathrm{c}-\mathrm{d}(9.71)$ & \\
\hline $\mathrm{B} 5+1.0 \mathrm{mg} \mathrm{L}^{-1} 2,4-\mathrm{D}+0.8 \mathrm{mg} \mathrm{L}^{-1} 2 \mathrm{iP}$ & $5.0 \mathrm{c}-\mathrm{d}(7.39)$ & \\
\hline $\mathrm{B} 5+1.5 \mathrm{mg} \mathrm{L}^{-1} 2,4-\mathrm{D}+0.8 \mathrm{mg} \mathrm{L}^{-1} 2 \mathrm{iP}$ & $5.0 \mathrm{c}-\mathrm{d}(7.39)$ & \\
\hline $\mathrm{B} 5+1.5 \mathrm{mg} \mathrm{L}^{-1} 2,4-\mathrm{D}+0.5 \mathrm{mg} \mathrm{L}^{-1} 2 \mathrm{iP}$ & $2.5 \mathrm{c}-\mathrm{d}(5.35)$ & \\
\hline $\mathrm{B} 5+2.0 \mathrm{mg} \mathrm{L}^{-1} 2,4-\mathrm{D}+0.1 \mathrm{mg} \mathrm{L}^{-1} 2 \mathrm{iP}$ & $2.5 \mathrm{c}-\mathrm{d}(5.35)$ & \\
\hline
\end{tabular}

\section{3. Embriyoların bitkiciğe dönüşümü}

C. persicum türünden izole edilen ovül örnekleri ilk olarak kallus oluşturma ortamlarına aktarılmış ve karanlıkta 16 hafta kültüre alınmıştır. Kallus uyartımı başladıktan sonra eksplantlar aynı koşullarda embriyojenik kallus oluşuncaya kadar kültüre alınmış ve son olarak (ortalama 16 hafta sonra) kallus yapıları farklılaşma ortamına (hormonsuz besi ortamı) transfer edilmiştir. Farklılaşma ortamına transfer edilen kalluslarda embriyo uyartımı sağlanmıştır. Kültürün ilerleyen safhalarında embriyolar normal gelişme aşamalarını (globüler safha, kalp safhası, torpedo safhası, kotiledon safhası) tamamlayarak sürgün oluşturmuştur. Yaklaşık 32 hafta sonra gelişen embriyolardan bitkiciğe dönüșüm sağlanmıștır. Çalıșma kapsamında her ne kadar kallus oluşumu ve embriyo uyartımı farklı besi ortamlarında gerçekleşmiş̧ olsa da sağlıklı bitkilerin oluşumu sadece $2.0 \mathrm{mg} \mathrm{L}^{-1} 2,4-\mathrm{D}$ ve $0.5 \mathrm{mg} \mathrm{L}^{-1} 2$ iP içeren $1 / 2 \mathrm{MS}$ ortamının başlangıç ortamı olarak kullanıldığ 1 ortamlardan gelişen embriyolardan (42 adet bitki) elde edilmiştir (Şekil 7). Diğer besi ortamlarında oluşan embriyolar gelişimini tamamlamış ancak bitkiciğe dönüşmemiştir. $\mathrm{Bu}$ nedenle bitkiciğe dönüşüm oranı hesaplanamamıștır. C. pseudibericum türünden izole edilen ovüllerden ise kallus oluşumu gerçekleşmiş ancak bir müddet sonra oluşan kallus yapıları siyahlaşarak gelişimini tamamlamış ve sonrasında bir farklılaşma gözlenmemiştir.

\section{Tartışma}

\section{1. Eksplantlardan kallus gelişimi}

Çalışma kapsamında biri endemik (C. pseudibericum) diğeri ise ülkemiz florasında doğal olarak yayılış gösteren $(C$. persicum) ve ticari çeşitlerin atası olarak kabul edilen iki farklı siklamen türünden izole edilen ovüller ilk olarak kallus uyartım ortamında kültüre alınmıştır. Kallus uyartımında, 2,4-D ve $2 \mathrm{iP}$ büyüme düzenleyicilerinin farklı kombinasyonlarını içeren $1 / 2 \mathrm{MS}$ ve $\mathrm{B} 5$ besi ortamlarının etkileri araştırılmıştır.

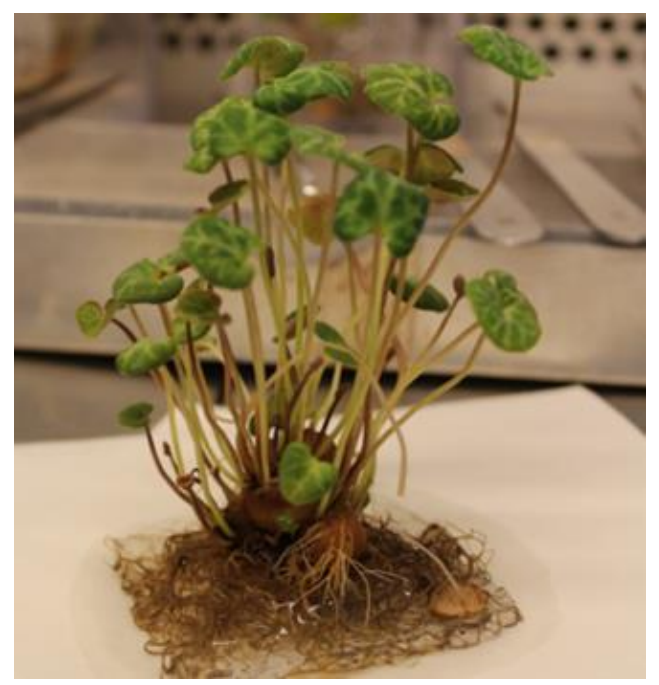

Şekil 7. C. persicum ovül eksplantlarından elde edilen bitkiciklerin görünümü

Ovüllerden kallus oluşumunda $C$. persicum türünde besi ortamlar arasında istatistiksel olarak bir fark bulunmazken, hormon bileşimi ve besi ortamı-hormon interaksiyonu önemli bulunmuştur. $1.5 \mathrm{mg} \mathrm{L}^{-1} 2,4-\mathrm{D}$ ve $0.5 \mathrm{mg} \mathrm{L}^{-1} 2 \mathrm{iP}$ içeren $\mathrm{B} 5$ ortamında kallus gelişim oranı $\% 70$ olmuştur (Çizelge 1). C. pseudibericum türünden izole edilen ovül eksplantlarından kallus rejenerasyon oranı ise $\% 32$ ile $\% 48$ arasında değişmiştir. Kallus uyartımında her ne kadar besi ortamları arasındaki fark istatistiki açıdan önemli çıkmasa da kallus gelişim oranındaki artışın besi ortamından kaynaklandığı düşünülmektedir. Kreuger (1996) yapmış olduğu çalışmada düşük amonyum konsatrasyonlu B5 ortamının siklamende kallus uyartımının KK besi ortamına göre daha iyi sonuç verdiğini belirlenmiştir. Çalışma kapsamında kullandığımız besi ortamlarının 
içeriği incelendiğinde B5 ortamında bulunan amonyum konsatrasyonu $1 / 2 \mathrm{MS}$ ortamından daha düşüktür. $\mathrm{Bu}$ durum, B5 ortamında kallus uyartımının daha iyi olmasının bir nedeni olabilir. Winkelmann ve Serek, (2005) 32 F1 hibrit siklamen çeşidinde yapmış olduğu çalışmalarında ovül kültüründe \%5-42 arasında kallus rejenerasyonu elde etmişlerdir. Her iki türdeki kallus rejenerasyon oranını birlikte değerlendirdiğimizde çalışma kapsamında kallus rejenerasyonu \%32-\%70 arasında değişmiştir. Koçak ve ark. (2014) ülkemizde doğal olarak yayılış gösteren 15 Cyclamen persicum genotipinde yapmış oldukları çalışmada ovül eksplantından kallus rejenerasyon oranını ortalama $\% 26.66$, en yüksek ise (bir genotip için) \%100 olarak bildirmişlerdir. $\mathrm{Bu}$ çalışma sonucunda kallus rejenerasyon oranı önceki çalışmalara göre kısmen düşük olmakla birlikte sonuçlar büyük ölçüde benzerlik göstermektedir. Kallus rejenerasyonunun düşük olması doğadan toplanan materyallerin kullanılmasından kaynaklanabilir. In vitro kallus uyartımı eksplant kaynağının fizyolojik durumu ve genetik faktörlerin etkisi altındadır. Bu durum aynı zamanda biyokimyasal ve fizyolojik açıdan hormonların absorbe edilmesini ve kallus oluşumunda hücresel yeteneği etkilemektedir (Sharma ve Nautiyal, 2009). Bu nedenle kallus oluşum oranının türler ve genotipler arasında farklılık göstermesinin en önemli nedenlerinden biri de eksplant kaynă̆ının genetik yapısıdır.

Loewenberg (1969) yapmış olduğu çalışmada siklamen yumrularında rejenerasyon optimizasyonu yapmıştır. Farklı karbon kaynaklarının denendiği çalışmada sükroz dışındaki karbon kaynaklarında (maltoz, fruktoz, glikoz) kallus gelişiminin daha düşük olduğunu bildirmiştir. Eksplant kaynağı olarak ovülü kullandığımız çalışmamızda karbon kaynağı olarak sükroz kullanılmakla birlikte, B5 ortamı $262.9 \mathrm{mM} \mathrm{L}^{-1}$ maltoz da içermektedir. Loewenberg (1969) bildirdiğinin aksine, kallus uyartımında besi ortamları arasında istatistiki bir fark bulunmamıştır. Bu durum büyük ölçüde eskplant kaynağının farklı olmasından kaynaklanmaktadır. Genel olarak her iki tür içinde kallus rejenerasyonu gerçekleşmiştir. Ancak, $C$. pseudibericum türüne ait ovül eksplantlarından kallus rejenerasyonu gerçekleşmiş ve sonrasında kallus siyahlaşarak gelişimini tamamlamıştır. Bu durum her iki besi ortamında da gözlenmiştir. Kreuger (1996) yaptığı çalışmada yüksek amonyum konsantrasyonunun in vitro rejenerasyonda siklamen için toksik etkiye sahip olduğunu bildirmiştir. $\mathrm{Bu}$ nedenle, MS ortamındaki yüksek amonyumun $C$. pseudibericum türünde kallusların gelişimini inhibe etmiş olabileceği düşünülmektedir. Ancak, her iki besi ortamında da bu durumun gözlenmiş olması kallus gelişiminin ve farklılaşma olmamasının nedeninin sadece amonyum konsantrasyonuna bağlanamayacağını göstermektedir. Çünkü B5 ortamının amonyum içeriği, $1 / 2 \mathrm{MS}$ ortamında bulunan amonyum miktarından daha azdır. Bu durumun alternatif nedenleri ise genetik yap1, hücrenin rejenerasyon kapasitesinin düşük olması ya da kullanılan ortam bileşenlerinden kaynaklanan toksik etki olabilir.

İzgü ve ark. (2016) çalışmalarında $C$. pseudibericum ovül örneklerinden kallus oluşum oranı en yüksek $2.5 \mathrm{mg} \mathrm{L}^{-1} 2,4-\mathrm{D}+0.5 \mathrm{mg} \mathrm{L}^{-1} 2$ iP içeren ortamda (\%20) gerçekleşmiştir. Araştırıcılar, çalışmalarında yaprak, yaprak sapı, ovaryum ve ovül örneklerini kullanmışlar ve ovül örneklerinde kallus oluşumunun daha düşük olduğunu bildirmişlerdir. İzgü ve ark., (2016)'nin sonuçları ile çalışmamız sonuçları benzer olup, her iki çalışmada da düşük oranda sitokinin ile birlikte kullanılan oksin büyüme düzenleyicisinin kallus rejenerasyonunda etkili olduğu bulunmuştur. Ancak, ortamda bulunan yüksek 2,4-D konsantrasyonu da yüksek amonyum konsantrasyonu gibi kallus rejenerasyonunu inhibe edebilmektedir. Bu durumun, yüksek 2,4-D konsantrasyonunun etilen üretimini arttırmasından kaynaklanabileceği bildirilmiştir (George ve ark., 2008; İzgü ve ark., 2016).

C. persicum türünde ovüllerden $1 / 2 \mathrm{MS}$ ortamında gelişen kallus yapılarında kallusların dokusunun yumuşak, kallus renk koyuluğunun orta koyulukta ya da açık olduğu, kallus renginin ise kahverengi ve sar1 tonları arasında geçiş yaptığı gözlenmiştir. Ayrıca $1 \frac{1}{2} \mathrm{MS}$ besiyerinde oluşan kallusların yapısının B5 ortamında oluşan kalluslara göre daha kırılgan yapıya sahip oldukları gözlenmiştir. C. pseudibericum türünden alınan ovül eksplantlarından gelişen kallus yapıları, $C$. persicum türü ile benzerlik göstermiştir. Ancak $C$. pseudibericum türünden gelişen kalluslar zamanla kahverenginden siyaha dönmüş ve canlılı̆̆ını yitirmiştir. Önceki çalışmalara göre kallus yapıları ile embriyo uyartımı arasında bir korelasyon bulunmamaktadır (Schween ve Schwenkel, 2003; Winkelmann ve Serek, 2005). Çalışmamızda da incelenen kallus dokularının farklı yapılarda veya renkte olmasının rejenerasyon ile ya da embriyo uyartımı ile bir bağlantısının olmadığı düşünülmektedir.

\subsection{Embriyo Uyartımı ve Çimlenmesi}

Yapılan çalışmada embriyo uyartımı sadece $C$. persicum türünde sağlanabilmiştir. En yüksek embriyo uyartımı; $1.5 \mathrm{mg} \mathrm{L}^{-1} 2,4-\mathrm{D}$ ve $0.8 \mathrm{mg} \mathrm{L}^{-1} 2$ iP içeren besi yerinde ortalama $\% 30$ oranında gerçekleşmiştir. Bunu $1.5 \mathrm{mg} \mathrm{L}^{-1} 2,4-\mathrm{D}+0.1 \mathrm{mg} \mathrm{L}^{-1} 2 \mathrm{iP}(\% 20)$ ve $2.0 \mathrm{mg} \mathrm{L}^{-1}$ $2,4-\mathrm{D}+0.8 \mathrm{mg} \mathrm{L}^{-1} 2 \mathrm{iP}(\% 16.8)$ takip etmiştir (kullanılan hormon ve besi ortamı interaksiyonu istatistiki olarak önemli bulunduğundan tüm veriler verilmemiştir). Besi ortamı hormon interaksiyonu göz önünde bulundurulduğunda $C$. persicum türünde $1.5 \mathrm{mg}$ $\mathrm{L}^{-1}$ 2,4-D ve $0.8 \mathrm{mg} \mathrm{L}^{-1}$ 2iP içeren $1 / 2 \mathrm{MS}$ besi ortamından embriyo uyartım oranı, $\% 55$ olmuştur. $\mathrm{Bu}$ oran, $2 \mathrm{mg} \mathrm{L}^{-1}$ 2,4-D ve $0.8 \mathrm{mg} \mathrm{L}^{-1} 2 \mathrm{iP}$ içeren B5 ortamında \%30 olarak bulunmuştur (Çizelge 3). Çalışmada besi ortamlarının embriyo uyartımı üzerine etkisi istatistiksel olarak önemli bulunmasa da besi ortamı ve hormon interaksiyonuna bakıldığında besi ortamının etkisinin yadsınamayacak derecede yüksek 
olduğu tahmin edilmektedir. Çünkü en yüksek embriyo uyartımı (\%30) $1.5 \mathrm{mg} \mathrm{L}^{-1}$ 2,4-D ve $0.8 \mathrm{mg} \mathrm{L}^{-1} 2 \mathrm{iP}$ hormon konsantrasyonu içeren besi ortamında gelişen kalluslardan elde edilmiştir. Ancak, aynı hormon konsantrasyonunu içeren $1 / 2 \mathrm{MS}$ ortamında embriyo uyartımı \% 55 iken aynı hormon bileşimini içeren B5 ortamında embriyo uyartımı sadece \% 5'dir. Bu nedenle embriyo uyartımının $1 / 2 \mathrm{MS}$ besi ortamında daha iyi gerçekleştiğini söyleyebiliriz. Koçak ve ark. (2014) ülkemizde doğal olarak yetişen 15 farklı Cyclamen persicum genotipinden izole edilen ovül eksplantlarında embriyo uyartım oranının \%2.83-11.3 olduğunu bildirmişlerdir. Amini (2014) ise yine ülkemizde doğal olarak yetișen ve kültüre alınan Cyclamen persicum genotiplerinde yapmış olduğu çalışmada embriyo uyartım oranının \%3.92-38.74 arasında değiştiğini bildirmiştir. Çalışmamızda ovül eksplantlarından embriyo uyartımı bu çalışmalardaki oranlara göre daha yüksek bulunmuştur. Prange ve ark., (2010) ise yine Cyclamen persicum türünden izole edilen ovüllerden elde edilen embriyo uyartım oranını \%11 ile \%60 arasında olduğunu bildirmiştir. Bu sonuç çalışmamızda elde ettiğgimiz sonuçlardan nispeten daha iyidir. Bizim çalışmamız ile yukarıda belirtilen üç çalışmada da benzer ortamlar ve hormon içerikleri kullanılmakla birlikte embriyo uyartım oranları arasında belirgin bir farkl11ık görülmektedir. Bu durumun en belirgin nedeni olarak, çalışmalarda her ne kadar aynı türe ait bireyler kullanılmış olsa da genotip etkisinin ön plana çıkmasından kaynaklandığı düşünülmektedir. Takamura ve ark., (1995) orta düzeyde 2,4-D $(5.0 \mu \mathrm{M})$ kullanımının kallus rejenerasyonunu arttırdığını, aynı zamanda embriyo farklılaşmasını durdurabileceği veya geciktirebileceğini bildirmiştir. Prange ve ark., (2010) ise çalışmalarında $C$. persicum türünde embriyo uyartımının artış göstermesinin nedenini besi ortamına fazladan eklenen $\mathrm{CaCl}_{2}$ 'e dayandırmıştır. Ancak, Püschel ve ark., (2003) C. persicum türünde yapmış oldukları çalışma sonucunda siklamen genotiplerinde embriyo rejenerasyon yeteneğinin genetik yapının kontrolü altında olduğunu bildirmişlerdir. $\mathrm{Bu}$ nedenle, her nekadar embriyo uyartımında kullanılan besi ortamının ya da hormonların farklı etkisi olsa da temelde genetik yapının rejenerasyon yeteneğine sahip olması gerekmektedir. Çünkü, besi ortamındaki elementlerin ve ortama ilave edilen büyüme düzenleyicilerinin hücreye alınımı ve besi ortamı içeriğine verilen tepkiler yine genetik yapı ile yakından ilişkilidir.

C. persicum türünden izole edilen ovül eksplantlarından sadece $2.0 \mathrm{mg} \mathrm{L}^{-1} 2,4-\mathrm{D}$ ve $0.5 \mathrm{mg} \mathrm{L}^{-1}$ $2 \mathrm{iP}$ içeren $1 / 2 \mathrm{MS}$ ortamına alınan ovüllerden bir tanesinden rejenere olan kallus yapısından embriyoların çimlenmesi ile 42 adet bitkicik oluşumu sağlanmıştır. Diğer hormon konsantrasyonlarında embriyo uyartımı gerçekleşmesine rağmen embriyolar farklılaşmasını tamamlayamamış ve bitkiciğe dönüşüm gerçekleşmemiştir. Embriyo uyartımından sonra bitkiciğe dönüşümün düşük kalması, embriyoların gelişimindeki anormalliklerden, embriyo gelişiminin homojen olmamasından, embriyoların kültür ortamı içerisinde birbiri ile kaynaşarak şekillerinin ve yapılarının bozulmasından, kültür ortamı süresince embriyojenik yeteneğinin zamanla kaybolmasından kaynaklanabilmektedir (Winkelmann ve ark., 2015; Tütüncü ve ark., 2016).

\section{Sonuc}

Dünyada süs bitkileri yetiştiriciliğinde kullanılan biyoteknolojik yöntemlerin başında şüphesiz in vitro teknikler ön sırada yer almaktadır. Özellikle kendileme depresyonunun görüldüğü siklamen gibi türlerde ise in vitro haploidizasyon teknikleri kullanılmaktadır. Ayrıca siklamen geleneksel olarak tozlama ile üretilen ve bu nedenle pahalı olan tohumları ile çoğaltılmaktadır. Siklamen kendileme depresyonu gösterdiği için F1 hibritlerin ebeveyn hatlarının çoğaltımı zordur. $\mathrm{Bu}$ nedenle 1slahçılar ıslah programlarında vegetatif çoğaltmaya önem vermektedirler. Ancak tür, çeşit hatta genotipler arasında görülen reaksiyon farklılıkları hem in vitro haploidizasyon hem de in vitro klonal çoğaltım için çoğunlukla farklı doku kültürü protokollerini gerektirmektedir. $\mathrm{Bu}$ yüzden, öncelikle bitkisel materyale uygun doku kültürü protokolünün oluşturulması ve doku kültüründe etkili olan faktörlerin değerlendirilmesi gerekmektedir.

Yapılan çalışma kapsamında yukarıda belirtilen hedefler doğrultusunda ülkemiz florasında doğal yayılış gösteren ve popülasyon yoğunluğu yüksek olan $C$. persicum türü ile ülkemize endemik $C$. pseuidbericum türlerinin gynogenezis yeteneği ve buna etki eden farklı besi ortamları ile hormon konsantrasyonlarının etkisi araştırılmıştır. Çalışmada 2,4-D (0.5-1.0-1.5 ve $2.0 \mathrm{mg}$ $\left.\mathrm{L}^{-1}\right)$ ve $2 \mathrm{PP}\left(0.1-0.3-0.5\right.$ ve $\left.0.8 \mathrm{mg} \mathrm{\textrm {L } ^ { - 1 }}\right)$ büyüme düzenleyicilerinin kombinasyonlarının bulunduğu $1 / 2 \mathrm{MS}$ ve $\mathrm{B} 5$ besi ortamları denenmiştir. Sonuç olarak $C$. persicum türünde kallus uyartımı, embriyo uyartımı ve bitkiciğe dönüşüm başarılı bir şekilde gerçekleştirilirken, $C$. pseudibericum türünde kallus uyartımı gerçekleşmiş ancak embriyo uyartımı ve bitkiciğe dönüşüm sağlanamamıştır. Bu durumun ortaya çıkmasındaki en önemli faktörlerin başında, eksplant kaynağının genetik yapısı, rejenerasyon yeteneği ve eksplant kaynağının fizyolojik durumu gelmektedir. $\mathrm{Bu}$ nedenle, sonraki çalışmalarda aşağıdaki konuların göz önünde bulundurulması çalışmaların başarısını arttıracaktır.

Siklamen genotiplerinde rejenerasyon büyük ölçüde genetik yapıyla bağlantılıdır. Siklamende yapılan çalışmalarda rejenerasyon yeteneğinin bir çift dominant gen ile kontrol edildiği belirtilmektedir. Bu nedenle, siklamende in vitro çalışmalarda başlangıç materyallerinin öncelikle rejenerasyon yeteneği test edilmeli, sonrasında rejenerasyon yeteneği yüksek genotipler arasından model bitki seçilerek çalışmalar bu genotiple yürütülmelidir. Böylece çalı̧̧mada genotip etkisi ortadan kaldırılabilir ve daha başarılı sonuçlar 
alınabilir.

Önceki çalışmalarda da belirtildiği üzere siklamende düşük amonyum içeriğinde rejenerasyon başarısı artarken, yüksek amonyum miktarı toksik etkiye neden olabilmektedir. $\mathrm{Bu}$ nedenle düşük amonyum konsanrasyonuna sahip besi ortamları tercih edilmeli ya da kullanılan besi ortamları modifiye edilmelidir. Ayrıca, yapılan çalışmalarda kallus yapılarından embriyo uyartımında besi ortamına ilave edilen $\mathrm{CaCl}_{2}$ 'ün embriyo rejenerasyonunu $\operatorname{arttırdığ~} \mathrm{da}$ belirlenmiştir.

\section{Kaynaklar}

Abak, K., 1993. Biber 1slahında anter kültürlerinden yararlanma, Bitki Islahı Sempozyum Bildirileri, TÜBİTAK TOAG, 59-66.

Amini, L., 2014. Bazı siklamen türlerinde (C. cilicium, $C$. persicum ve $C$. hederifolium) anter ve ovül kültürü yöntemlerinin embriyo uyartımına etkileri. Yüksek Lisans Tezi. Çukurova Üniversitesi Fen Bilimleri Enstitüsü, 57s, Adana.

Curuk, P., Sogut, Z., Bozdogan, E., Izgu, T., Sevindik, B., Tagipur, E. M., Teixeira Da Silva, J. A., Serce, S., Kacar, Y. A., Mendi, Y. Y., 2015. Morphological characterization of Cyclamen $s p$. grown naturally in Turkey: Part I. South African Journal of Botany, 100: 7-15.

Dunwell, J. M., 2010, Haploids in flowering plants: origins and exploitation. Plant Biotechnology Journal, 8: 377-424.

Ellialtıoğlu, Ş., Sarı, N., Abak, K., 2001. Haploid bitki üretimi. Babaoğlu, M., Gürel, E., Özcan, S. (Eds.). Bitki biyoteknolojisi I - Doku Kültürü ve Uygulamaları, 2. Baskı, Selçuk Üniversitesi Vakfı Yayınları, Konya, 137-189.

Emiroğlu, Ü., 1980, Tütün çeşitlerinde anter kültürü. Ege Zirai Araştırma Enstitüsü, 17(41): 12-18.

Gamborg, O. L., Miller, R. A., Ojima, K., 1968. Nutrient requirements of suspension cultures of soybean root cells. Exp Cell Res. 50(1):151-8.

George, E. F., Hall, M. A., De Klerk, G. J., 2008. The components of plant tissue culture media I: macroand micro-nutrients. In: George, E. F, Hall M. A., De Klerk G. J. (Eds). Plant Propagation by Tissue Culture 3rd Edition, Springer, Berlin, 479.

İzgü, T., Sevindik, B., Çürük, P., Şimşek, Ö., Kaçar, Y. A., Teixeira da Silva, J. A., Mendi, Y. Y., 2016. Development of an efficient regeneration protocol for four Cyclamen species endemic to Turkey. Plant Cell Tiss Organ Cult., 127: 95-113.

Jalali, N., Naderi, R., Shahi-Gharahlar, A., Teixeira Da Silva, J. A., 2012. Tissue culture of Cyclamen, Scientia Hort., 137: 11-19.

Kamanetsky R., Okubo H., 2013. Ornamental Geophytes From Basic Science To Sustainable Production. CRC Press, London, XV-XVII.

Koçak, M., İzgü, T., Sevindik, B., Tütüncü, M., Çürük, P., Şimşek, Ö., Kaçar, Y. A., Teixeira da Silva, J. A.,
Mendi, Y. Y., 2014. Somatic embryogenesis of Turkish Cyclamern persicum Mill. Scientia Horticulturae, 172: 26-33.

Kreuger, M., Induction of plant somatic embryogenesis in liquid medium, Wageningen. http://edepot.wur.nl/210303 (Ziyaret tarihi: 19.02.2019).

Loewenberg, J. R., 1969. Cyclamen callus culture. Can. J. Bot., 47: 2065-2067.

Mathew, B., Özhatay, N., 2001. Türkiye'nin Siklamenleri, Türkiye'de Doğal Olarak Yetişen Siklamen Türlerinin Tanıtım Rehberi, Doğal Hayatı Koruma Derneği, 32s, İstanbul.

Murovec, J., Bohanec, B., 2012. Haploid and soubled haploids in plant breeding. In: Abdurakhmonov, I.Y. (Ed.). Plant Breeding, Intech, 87-106.

Mishra, V. K., Goswami, R., 2014. Haploid productions in higher plant. IJCBS Review Paper vol. 1, 25-44.

Murashige, T., Skoog, F. (1962). A revised medium for rapid growth and bio assays with tobacco tissue cultures. Physiologia plantarum, 15(3):473-497.

Prange, A. N. S., Serek, M., Bartsch, M., Winkelmann, T., 2010, Efficient and stable regeneration from protoplasts of Cyclamen coum Miller via somatic embryogenesis. Plant Cell Tiss Organ Cult., 101: 171-182.

Püschel, A.K., Schwenkel, H.G., Winkelmann, T., 2003. Inheritance of the ability for regeneration via somatic embryogenesis in Cyclamen persicum. Plant Cell Tissue Organ Cult. 72: 43-51.

Schween, G., Schwenkel, H. G., 2003. Effect of genotype on callus induction, shoot regeneration, and phenotypic stability of regenerated plants in the greenhouse of Primula spec., Plant Cell Tiss Org Cult., 72: 53-61.

Sharma G., Nautiyal AR., 2009. Influence of explants type and plant growth regulators on In vitro multiple shoots regeneration of a Laurel from Himalaya. Nature and Science, 7(9).

Sita, G. L., 1997. Gynogenic haploids in vitro. In: Jain, S.M., Sopory, S.K., Veilleux, R.E. (Eds.). In vitro Haploid Production in Higher Plants, Springer Science+Business Media B.V., Netherlands, 175193.

Takamura, T, Miyajima, I., Matsuo, E., 1995. Somatic embryogenesis of Cyclamen persicum Mill. 'Anneke' from aseptic seedlings. Plant Cell Reports, 15: 2225.

Tütüncü, M., Mendi, Y. Y., Ratjens, S., Bartsch, M., Winkelmann, T., 2016. Sitokinin uygulamalarının siklamende (Cyclamen persicum L.) somatik embriyoların farklılaşması üzerine etkileri. VI. Süs Bitkileri Kongresi bilidiri özet kitabı, 19-22 Nisan, Antalya.

Tütüncü, M., İzgü, T., Sevindik, B., Mendi Y.Y., 2017. In vitro haploidy techniques in ornamental plants. Research Journal of Agricultural Sciences, 10(1): 01-06. 
Winkelmann, T., Ratjens, S., Bartsch, M., Rode, C., Niehaus, K., Bednarz, H., 2015. Metabolic profiles of Somatic embryos of Cyclamen persicum in comparison to zygotic embryos, endosperm and testa. Front. Plant Sci., 6: 597.

Winkelmann, T., Serek, M., 2005. Genotypic differences in callus formation and regeneration of somatic embryos in Cyclamen persicum Mill. Euphytica, 144: 109-117.

Yılmaz, Ö. E., 2005. Yazlık kabakta (Cucurbita pepo L.) ovaryum kültürü yoluyla haploid bitki eldesi. Yüksek Lisans Tezi. Kahramanmaraş Üniversitesi Fen Bilimleri Enstitüsü, 55s, Kahramanmaraş. 